\title{
Carsten Bergenholtz*
}

\section{Videnskabelig (u)redelighed - også et tema for lingvistik}

\begin{abstract}
The debate about scientific dishonesty over the last few years has revealed differences and confusion regarding scientific dishonesty. Every branch of science ought to have well-established criteria for scientific dishonesty, to be able to distinguish between sloppy science and dishonest science. Sc. dishonest behaviour is characterized by being dishonest or reckless, and by twisting the scientific message. The aim of this article is to a) provide a list of criteria to define scientific dishonesty, and b) exemplify and discuss specific linguistic aspects of the discussion. Furthermore it will be argued that agreeing on common rules is not enough as general rules can be interpreted differently. Therefore a common judgement is necessary, i.e. a committee, either local or national. It is recommended that any local institution establishes a committee of their own.
\end{abstract}

\section{Indledende overvejelser}

Udtrykket "videnskabelig uredelighed” var indtil for få år siden stort set ukendt for den almindelige danske sprogbruger. Polemikken omkring Bjørn Lomborg og Udvalgene Vedrørende Videnskabelig Uredelighed (UVVU) har dog medført, at udtrykket er blevet flittigt brugt i det danske sprog. Men hvad betyder udtrykket "videnskabelig uredelighed", og hvad drejer den omfangsrige diskussion sig egentlig om?

I dagspressen diskuteres primært, hvorvidt Lomborg er videnskabelig uredelig, eller hvorvidt han evt. er objektivt uredelig eller måske blot har brudt nogle blødere normer for god videnskabelig skik. Set fra et videnskabsetisk synspunkt har det primære problem i Lomborg-sagen netop været denne forvirring omkring videnskabsetiske normers status. Hvad er kriterierne for videnskabelig uredelighed? Hvor går grænsen

* Carsten Bergenholtz Institut for Filosofi og Idehistorie, Afdeling for Filosofi Århus Universitet DK-8000 Arhus C carsten@bergenholtz.dk 
mellem uacceptabel og uredelig videnskab, og redelig og acceptabel videnskab? Og er udtrykket "objektivt uredeligt" overhovedet et meningsfuldt dansk udtryk? (Bl.a. brugt af Jens Morten Hansen, direktør for Forskningsstyrelsen, www.forsk.dk/uvvu/nyt/presse/lomborg pres.htm).

En lingvist kunne spørge sig selv, om det ikke kun er inden for samfundsvidenskaberne, at det kan være besværligt at bestemme grænsen mellem redelig og uredelig adfærd? Følgende 4 eksempler er med til at illustrere, hvorfor en sådan grænsedragning også kan være problematisk indenfor lingvistikken.

- Forsker A har i sin seneste artikel et afsnit på 12 ord, der fremstår som forsker A's egen produktion, men faktisk er et citat.

- Forsker B har 3-4 kortere redegørende afsnit, der viser sig at være hentet fra en ældre lærebog.

- Forsker $\mathrm{C}$ har en konsekvent mangel på henvisninger i sin artikel på trods af, at den viser sig at indeholde 6-7 længere citater.

- Forsker D’s artikel er en oversættelse af en polsk tekst uden nogen form for henvisning.

Eksemplerne henviser til det måske mest udbredte problem inden for alle videnskaber, nemlig snyd i form af plagiat. Her tænkes der både på bevidst snyd, men også fejl der skyldes sløsethed. Det er en problemstilling, der både angår seniorforskeren, men også den unge studerende, der afleverer en eksamensopgave. Der er ingen tvivl om, at alle handlinger i ovenstående eksempler er forkerte, men hvornår bliver en forkert adfærd til en uetisk, dvs. decideret videnskabeligt uredelig adfærd? Hvis en forsker eller studerende har glemt en enkelt anvisning på et citat, er der vel i udgangspunktet ikke tale om videnskabelig uredelighed?

Det er dog ikke kun ang. plagiat, at diskussionen omkring videnskabelig uredelighed er relevant for lingvistikken. Diskussionen om Lomborgs (u)redelighed handler primært om selektivitet, og samme problemstilling kunne opstå i lingvistik, jf. følgende hypotetiske eksempel: I forbindelse med udarbejdelsen af en ordbog foretager en forsker en undersøgelse af udtrykket antisemit. Forskernes forslag til en definition er stærkt normativ og udløser en voldsom politisk betændt diskussion og anklager om, at forskeren har været ensidig i udvælgelsen af, hvilke 
dagblade, bøger og lignende der er blevet foretaget en deskriptiv undersøgelse af.

Lingvistikken vil ligesom samfundsvidenskaberne kunne generere politisk betændte diskussioner om forskeres evt. selektive form for videnskab.

Eksemplerne om plagiat og selektivitet er med til at fremhæve betydningen af, at der foreligger klare retningslinjer for, hvornår der er tale om acceptabel videnskab, hvorvidt det drejer sig om acceptable videnskabelige fejl, hvorvidt det evt. er samfundsdebatten, der unødigt har politiseret videnskaben, eller hvorvidt der måske er tale om uredelig videnskab, der i en eller anden grad skal påtales. Lomborg-sagen har understreget, hvor forstyrrende og uhensigtsmæssig tvivl om retningslinjerne kan være for videnskaben.

Men spørgsmålet er nu, hvorledes kriterier for videnskabelig uredelighed skal udformes? Kan kriterierne være universelt gældende, så lingvistikken evt. kan hente sine kriterier fra andre videnskabsområder? Eller må praktisk anvendelige retningslinjer tage hensyn til specielle lingvistiske forhold? I forlængelse af disse overvejelser om at bestemme kriterier for videnskabelig uredelighed, skal lingvistik som videnskabsområde samtidig være opmærksom på at have en fælles dømmekraft ang. fortolkningen af kriterierne, idet det vil være uhensigtsmæssigt om Århus og København eller Danmark og Finland havde en forskellig forståelse af reglerne.

I første omgang gives en generel og kort gennemgang af almene kriterier for videnskabelig uredelighed. I anden omgang konkretiseres undersøgelsen ved at uddybe konkrete problemstillinger og redegøre for, hvorledes de bør vurderes og behandles. Redegørelsen vil forsøge at anlægge en lingvistisk vinkel, når det er relevant. Afsluttende vil artiklen kort overveje, hvilken form for instans der skal autorisere og håndhæve retningslinjer for videnskabelig (u)redelighed.

\section{Generelle kriterier for videnskabelig uredelighed}

En af de primære opgaver for en definition af videnskabelig uredelighed er at få klarlagt grænsen mellem det, der er forkert og evt. en videnskabelig fejltagelse eller misforståelse og det, der er forkert og decideret vi- 
denskabeligt uredeligt. Følgende definition danner udgangspunkt for en belysning af denne grænse ${ }^{1}$ :

a) videnskabeligt uredelige handlinger er forsætlige eller groft forsømmelige, samtidig med at

b) handlingerne forfalsker eller forvrider det videnskabelige budskab, eller groft vildleder om ens indsats i forskningen.

Definitionen er således todelt; en uredelig eller groft forsømmelig adfærd er en nødvendig, men ikke en tilstrækkelig betingelse for konstitueringen af videnskabelig uredelighed. Det videnskabelige budskab skal samtidig være blevet forvredet. ${ }^{2}$ Første del understreger, at forskeren ikke nødvendigvis skal have haft en bedragerisk intention, men evt. kan have været ualmindeligt sløset i sit arbejde. Anden del fremhæver, at hvis det videnskabelige budskab ikke forvrides eller der ikke er foregået grov vildledning af ens indsats i forskningen, kan forskeren evt. erklæres uærlig, men ikke videnskabeligt uredelig.

Det skal tilføjes, at ikke alle lande arbejder med samme tilgang til uredelighedsbegrebet, som artiklens forståelse ovenfor giver udtryk for (Vik et al. 2001: 11-14). Især den lidt ældre diskussion om videnskabelig uredelighed har haft "fabrikation, falsifikation og plagiat" som kernepunkter. En anden tilgang har fokuseret på udtrykket "alvorlige afvigelser fra almindelig praksis". Der er dog flere problemer med disse tilgange. Førstnævnte vil ofte blive for smal og er i alle tilfælde for ukonkret i praksis. Den anden tilgang kan komme til at sætte restriktioner på en evt. revolutionerende videnskabelig udvikling, idet enhver videnskabelig revolution jo netop på fundamental vis ændrer almindeligt accepterede videnskabelige praksisser. Ved at fokusere på uærlighed og grov forsømmelighed forsøger denne artikel med sin tilgang at pege på et særligt og uomgængeligt træk ved videnskabelig uredelig adfærd.

1 Definitionen stammer oprindeligt fra en af Statens Sundhedsvidenskabelige Forskningsråd nedsat arbejdsgruppe (Andersen et al. 1992), der i 1992 publicerede den første danske rapport om videnskabelig uredelighed. Rapportens anbefalinger blev senere i vid udstrækning overført til UVVU’s bekendtgørelse.

2 Udtrykket "groft vildleder om ens indsats i forskningen" henviser udelukkende til adfærd som plagiat, uretmæssig angivelse af forfatterrolle, og fusk med ansøgninger, jf. nedenstående liste. 
En anvendelig konception af uredelighedsbegrebet må dog også kunne konkretisere, hvilke typer af handlinger der kan være uredelige. UVVU har til dette formål en liste på 9 punkter, der peger på forskellige kategorier af videnskabeligt uredelig adfærd.

- Konstruktion af data

- Selektiv og skjult kassation af uønskede resultater

- Substitution med fiktive data

- Bevidst vildledende anvendelse af statistiske metoder

- Bevidst forvredet fortolkning af resultater og forvridning af konklusioner

- Plagiering af andres resultater eller publikationer

- Bevidst fordrejet gengivelse af andres resultater

- Uretmæssig angivelse af forfatterrolle

- Ansøgninger med urigtige oplysninger ${ }^{3}$ (UVVU 2003: Bekendtgørelse for UVVU, § 3).

Listen skal læses i forlængelse af ovenstående todelte definition, og fremstår som et praktisk orienteret redskab til at bedømme, hvorvidt en videnskabelig adfærd evt. er uredelig. Det er vigtigt at understrege, at faglige uenigheder ang. f.eks. fortolkningen af resultater eller anvendelsen af statistiske metoder aldrig kan blive tilstrækkelige til at konstituere videnskabelig uredelighed. Misforståelser, uenigheder og fejltagelser er en del af den videnskabelige proces. Dette understreges af, at alle punkter på listen indeholder en forudsætning om et sindelagsmæssigt element. Forudsætningen kommer enten eksplicit til udtryk i ord som "bevidst, vildledende, forvredet", eller foreligger implicit, da plagiat nødvendigvis enten må skyldes snyd eller grov forsømmelighed. Idet enhver uredelig adfærd enten er uærlig eller groft forsømmelig, vil en forsker ikke kunne hævde: "Jamen jeg snød ikke, jeg vidste det bare ikke”, idet der kan stilles krav til, hvad en forsker bør vide i forskellige sammenhænge. En forsker kan derfor ikke blot forsvare sig med, at han ikke vidste, at afskrivning ikke var tilladt, eller at han ikke vidste, han ikke måtte slette data-serier, hvis ikke de passede i sammenhængen. Det

\footnotetext{
3 En optimeret udgave af denne liste vil ikke indeholde udtrykket "bevidst”. Udtrykket er overflødigt, da alle videnskabeligt uredelige handlinger er forsætlige eller groft forsømmelige. Udtrykket "bevidst” har dog muligvis den hensigt, at de pågældende punkter evt. ikke kan nøjes med at være groft forsømmelige, men netop skal være bevidste (Zahle 2003: 99). En sådan fortolkning er dog ikke blevet bekræftet af UVVU. Jeg gengiver her UVVU's version, idet alle former for videnskab, og således også den danske lingvist, skal arbejde i henhold til UVVU's nuværende retningslinjer.
} 
kan også være groft forsømmeligt, hvis forskeren ser bort fra en risiko om forvridning af det videnskabelige budskab (UVVU 1996: 31). På samme måde som en bilist skal kende til færdselsregler, skal en forsker kende til de etiske normer for sin praksis. Dvs. der kan arbejdes ud fra et krav om, hvad en forsker burde vide.

Konceptionen af videnskabelig uredelighed kan ikke blot indholdsbestemmes, men også gives en yderligere afgrænsning, da der kan nævnes forskellige former for kritisable handlinger, der ikke er tilstrækkeligt alvorlige til at konstituere egentlig videnskabelig uredelighed. Som eksempel kan nævnes dobbeltpublikation, opblæsning af en forskers publikationsliste, undladt omtale af andres tilgrundliggende, originale iagttagelser, mindre former for data-massage etc. (Andersen et al. 1992: 20-22). Nævnte eksempler kan blive tilstrækkeligt alvorlige til at konstituere uredelighed, men så kan de henføres til nogle af handlingerne i ovenstående liste. Eksemplerne er med til at understrege, at ikke alle ikke-redelige handlinger er decideret uredelige.

UVVU er den primære instans og autoritet, hvad angår håndteringen af videnskabelig uredelighed. Derfor er det nødvendigt at påpege, at UVVU gennem flere år har haft en beklagelig fortolkning af uredelighedsbegrebet. Dette forhold er blevet påpeget af bl.a. Henrik Zahle i Zahle 2003 og undertegnedes kronik i Berlingske Tidende januar 2004. Indtil videre har UVVU kun erkendt, at regelgrundlaget har behov for en justering (UVVU 2004: www.forsk.dk/uvvu/nyt/presse/lomborg_presse.htm).

UVVU skelner imellem uredelighedsbegrebets "objektive indhold" og "subjektive krav" (UVVU 1996: 31). Det "objektive indhold" refererer til ovenstående liste, mens de "subjektive krav" henviser til spørgsmålet om, hvorvidt handlingen er bevidst eller groft forsømmelig. UVVU har således givet sig selv muligheden for at påtale brud på det objektive kriterium, uden at det subjektive er overtrådt (og omvendt). En sådan påtale er i praksis lig med en påtale om "brud på god videnskabelig skik". Den oprindelige afgørelse af Lomborg-sagen fra januar 2003 indeholdt netop en sådan påtale. Med udgangspunkt i overvejelser om videnskabelig uredelighed kan UVVU således ende ud i en påtale om en mindre alvorlig adfærd, samtidig med at denne adfærd selvsagt vil blive associeret med videnskabelig uredelighed, som i Lomborgs tilfælde. 
Undersøges ovenstående liste nærmere, f.eks. handlingen "bevidst forvredet fortolkning af resultater og forvridning af konklusioner", må distinktionen afvises som værende uforståelig. For hvorledes skulle en "bevidst forvredet fortolkning" være uforsætlig, dvs. hvorledes skulle den undgå at overholde "det subjektive krav". Det forholder sig på samme måde for de andre punkter på listen; enhver konstruktion af data vil være forsætlig, og ethvert plagiat vil være forsætligt. Hvis forskeren hævder, at det ikke var med vilje, eller at det skyldes en forglemmelse, er der tale om grov forsømmelighed, og det subjektive krav vil derfor stadig være overtrådt. Er handlingen hverken uærlig eller groft forsømmelig, er den ikke tilstrækkelig alvorlig til at kunne blive karakteriseret som værende konstruktion af data. UVVU's fortolkning af deres egen bekendtgørelse er således inkonsistent og dybt problematisk.

Idet distinktionen er blevet brugt i konklusionen af Lomborg-afgørelsen fra januar 2003, er misforståelsen stadig udbredt i både den videnskabelige og den ikke-videnskabelige diskussion. F.eks. benyttes distinktionen i en bog om videnskabsetik af lektor Jacob Dahl Rendtorff (Rendtorff 2003: 58). Bogen er udgivet så sent som efteråret 2003. UVVU's distinktion er på alvorlig vis med til at sløre det væsentligste træk ved enhver form for videnskabelig uredelighed: Ucrlighed eller grov forsømmelighed. Eller positivt formuleret: Ærlighed og pålidelighed er grundtrækkene ved redelig videnskab. Hvis diskussionen i større grad formåede at fokusere på dette aspekt, ville den også blive mindre forvirret.

\section{Eksempler på videnskabeligt uredelig adfærd}

\subsection{At tælle forkert; en gang, flere gange, mange gange}

I nærværende afsnit vil diverse konkrete problemstillinger blive fremlagt og vurderet. Den første problemstilling er på sin vis simpel og drejer sig om at tælle forkert. Det kan ske for enhver, der arbejder med statistik. Foretager en forsker en lingvistisk undersøgelse af et ords frekvens, er det ikke nogen katastrofe, hvis resultatet via en enkelt forkert mellemregning lander på 2738, i stedet for det reelle 2739. Den forkerte mellemregning må karakteriseres som en fejltagelse og dårlig videnskab. Dog har fejltagelsen ikke en etisk karakter, da den ikke på nogen måde konstituerer upålidelighed. Inden for lægeindustrien eller 
astronomien kan en sådan mindre fejltagelse dog være skæbnesvanger, og forskellige videnskaber har derfor forskellige opfattelser af, hvor mange forkerte udregninger der skal til for, at der er tale om grov forsømmelighed.

Faget lingvistik må nu overveje, hvor mange af den slags fejltagelser der kan tolereres inden uredelighedsspørgsmålet bringes på banen. Indeholder en videnskabelig artikel mange af den slags forkerte mellemregninger er der i alle tilfælde tale om en ualmindelig dårlig produktion. Forskeren må også karakteriseres som værende upålidelig, og fejltagelserne har dermed et etisk perspektiv. Men er fejltagelserne blot tilfældige og uden noget formål, er der ikke tale om, at det videnskabelige budskab bliver "for-vredet" af forskeren. Adfærden falder således ikke ind under nogen af ovennævnte listes kategorier, dvs. forskerens handling svarer ikke til "konstruktion af data", eller "selektiv og skjult kassation af uønskede resultater" eller lignende. Forvridningen af det videnskabelige budskab opstår først, hvis der er en bias at spore i fejltagelserne, dvs. hvis fejltagelserne synes at have et formål, som afspejler sig i fortolkningen af resultaterne. I et sådant tilfælde vil der ikke længere være tale om fejltagelser, men selektiv og dermed uredelig videnskab. Spørgsmålet om selektiv videnskab vurderes nærmere i næste eksempel.

\subsection{At være selektiv}

Lomborg-sagen viser med al tydelighed, at det kan være utrolig svært at afgøre, hvornår en forsker evt. er selektiv, og om denne evt. ensidighed bør munde ud i en påtale om videnskabelig uredelighed. Selektivitet og bias er jo ofte ikke til at undgå. Både fordi det kvantitative videnskabelige omfang er massivt, men også fordi et videnskabeligt værk altid er udarbejdet efter en bestemt hypotese. Derfor vil der altid være en risiko for bias, den være sig bevidst eller ubevidst, som en forsker skal være opmærksom på og have en kritisk indstilling til. En manglende kritisk indstilling kan nemlig medføre en ensidig videnskabelig produktion. Det kan dog heller ikke udelukkes, at den pågældende forsker har været oprigtig og ikke udvist grov forsømmelighed, men stadig ikke har formået at overvinde sin egen subjektivitet. I en konkret situation må det derfor afvejes, hvorvidt forskeren burde have haft en bedre kritisk indstilling, dvs. hvor alvorlige fejltagelserne har været. 
For at anskueliggøre problemstillingen om selektivitet drages tidligere nævnte antisemit-eksempel frem igen. Der kan opstilles diverse scenarier, hvor en ensidig selektivitet både kan komme til udtryk i udvælgelsen af data og i behandlingen af data.

- Scenarium I: Forskeren erkender, at der kan spores en ensidighed i udvælgelsen af kilder.

- Scenarium II: Forskeren pointerer, at ikke al materiale kan indgå i undersøgelsen og benægter i modsætning til det øvrige videnskabelige samfund, at der har været tale om nogen form for ensidig udvælgelse.

- Scenarium III: I modsætning til de 2 første scenarier, er der i det videnskabelige samfund uenighed om, hvorvidt der er tale om en ensidig udvælgelse. Anklagen om videnskabelig uredelighed bliver fremsat af en part, der har en politisk interesse i sagen.

Der kan selvfølgelig opstilles mange flere scenarier, men ovenstående illustrerer nogle af hovedkategorierne. I alle tilfælde kan der kun være én overdommer: Det lingvistiske videnskabelige samfund. Hvis UVVU har sagen under behandling og ikke selv har sprogvidenskabelige folk siddende i udvalget, vil de naturligvis sende en forespørgsel til respekterede forskere i det videnskabelige samfund for at få en vurdering af sagen.

Ad scenarium I: Ideelt set bør der i dette tilfælde slet ikke være opstået nogen anklage om videnskabelig uredelighed, da forskeren i første omgang bør konfronteres for derved at få mulighed for at tage stilling til mistanken, uden at et stort sagsbehandlingssystem skal sættes i gang. Er sagen allerede forelagt UVVU, vil den blive afsluttet ved, at forskeren trækker sin artikel tilbage, og derfor vil en insisteren på en påtale om videnskabelig uredelighed være unødvendig.

Ad scenarium II: En forsker vil som tidligere nævnt ofte ikke kunne undgå at være selektiv i udvælgelsen af data. Spørgsmålet er nu, om selektiviteten er præget af en ensidighed, der forvrider det videnskabelige budskab. Hvis det videnskabelige samfund har en klar fælles vurdering af, at forskerens udvælgelse af data (eller behandling af data) i flere tilfælde bærer præg af en ensidighed, der konsekvent taler til fordel for forskerens konklusioner, er en mistanke om videnskabelig uredelighed på sin plads. Forskersamfundet må nu være meget opmærksom på at 
følge eksplicitte og entydige retningslinjer og overvejelser, der har en klar støtte fra det videnskabelige samfund. En påtale eller en dom om videnskabelig uredelighed er en meget hård dom for en forsker og stiller derfor strenge krav til retningslinjernes klarhed og dommens sikkerhed. Samtidig må det påpeges, at bevisbyrden ikke er den samme som i en retssal, hvor anklagemyndigheden skal bevise den anklagedes skyld. I videnskabelige sammenhænge må enhver forsker åbent kunne redegøre for sine skridt, og forskeren må derfor også altid være i stand til at redegøre for redeligheden af sine argumenter. Selektivitet kan være uundgåeligt, men skjult selektivitet giver en ensidig videnskabelig udvikling. I det her tilfælde bør sagen principielt set munde ud i, at forskeren får en påtale for videnskabeligt uredelig adfærd, hvad enten adfærden hævdes at være uærlig eller groft forsømmelig.

Ad scenarium III: En sådan sag vil minde om Lomborg-sagen, og derfor også have en tendens til at blive ualmindelig kompleks. I udgangspunktet kræver enhver påtale om videnskabelig uredelighed enighed i det videnskabelige bagland, og derfor er f.eks. 2/3 tilslutning ikke tilstrækkeligt. Det er muligt at kræve, at det videnskabelige samfund ikke kan tolerere uærlighed og grov forsømmelighed, men det er afgørende for den videnskabelige udvikling, at der er rum for uenighed om, hvilke standarder der kan stilles til selektion af data. Dette spørgsmål vil ydermere blive besvaret på vidt forskellig måde af de forskellige videnskabsgrene. Derfor vil det i nærværende scenarium ikke umiddelbart være muligt at give en påtale om videnskabelig uredelighed.

\subsection{Plagiat}

Plagiat er som tidligere nævnt det største problem indenfor videnskaben. Her tænkes der både på plagiat i form af afskrifter af hele videnskabelige værker, og på mindre afskrivninger, omskrivninger og manglende henvisninger. For en diskussion om uredelighedskriterier er plagiat $\mathrm{i}$ dets ekstreme form forholdsvis uproblematisk, da ingen kan hævde at være i tvivl om ulovligheden af det at skrive et helt videnskabeligt værk af.

Når det drejer sig om genbrug af tekstafsnit uden henvisninger, omskrivninger af ældre artikler eller brug af andres originale argumentation uden at henvise bliver det mere komplekst. Internettets voldsomme ekspansion kan gøre sådanne handlinger svære at opdage, især hvis stu- 
derende afskriver/oversætter udenlandske opgaver. Det skal her tilføjes, at hvis det er en 1. års studerende, der plagierer, er det ikke nødvendigvis videnskabelig uredelighed, men samme kriterier bør stadig være gældende.

I denne sammenhæng er det bemærkelsesværdigt, at to prominente danske personligheder inden for få måneder er blevet kritiseret for at gengive andres produktion uden at henvise. Poul Nyrup Rasmussen og Naser Khader er ikke videnskabsmænd, men det er stadigvæk stærkt kritisabelt og uredeligt, når de begge vælger at udgive bøger, der indeholder længere afsnit, der er direkte afskrifter. Det primære problem er netop den manglende bevidsthed om, at f.eks. afskrivning af et tekststykke er en alvorlig overtrædelse af helt fundamentale redelighedsprincipper. For at få oparbejdet denne bevidsthed, er det derfor afgørende, at studerende får stillet de samme krav som forskere. Enhver studerende må derfor også som minimum have et videnskabsteoretisk kursus, der bl.a. har til formål at give indblik i de principielle begrundelser for at skulle følge redelighedskriterier. Begrundelsen for at plagiat er uredeligt og forkert er ligetil: Det drejer sig om forskerens og argumentationens troværdighed og autoritet. Henvisninger er samtidig med til at give åbenhed omkring, hvorledes den videnskabelige argumentation er udformet. Det drejer sig således ikke blot om redelighedskriterier, men også om kvalitetskriterier.

Men hvilke kriterier bør lingvistik arbejde med? Skal der henvisning til en kendt 4-ords sætning? Skal der henvisning til en lærebog, hvis en videnskabelig artikel indeholder en kort redegørelse for et grundlæggende videnskabeligt begreb? Hvornår er et afsnit tilstrækkeligt omskrevet til, at det kan regnes for ens egen produktion? For det er jo ikke muligt blot at sætte henvisninger på alt, da en sådan fremgangsmåde vil gøre det videnskabelige arbejde for tungt.

Til et foredrag arrangeret af Dansk Selskab for Medicinsk Filosofi, Etik og Metode (efteråret 2003) mente den videnskabelige redaktør for Ugeskrift for Læger, Torben Schroeder, at 11 ord er grænsen for, hvornår der kan være tale om plagiat. Ethvert forsøg på at sætte tal på en grænse, må dog vurderes som værende håbløst. Selv et tekstafsnit på 5 ord kan kræve en henvisning. Der kan kun gives generelle retningslinjer og konkrete eksempler, som et udvalg i en konkret sag kan forsøge at arbejde ud fra. Det må også understreges, at en enkelt glemt henvisning 
i udgangspunktet ikke er tilstrækkeligt til at konstituere videnskabelig uredelighed. Betingelserne om uærlighed eller grov forsømmelighed og forvridning af det videnskabelige budskab er stadig gældende, og derfor skal det dreje sig om alvorlige eller gentagne tilfælde.

Som opsummering på nærværende afsnit vil der blive givet korte, principielle svar på de i afsnit 1 nævnte plagiat-eksempler:

- I forsker A og B's tilfælde kan der være tale om en forglemmelse eller uagtsomhed, og en korrektion og evt. en undskyldning vil ofte være tilstrækkeligt, afhængig af det lokale forskermiljøs traditioner.

- Forsker C, hvis tekst viser sig at indeholde 6-7 umarkerede citater, har et alvorligt forklaringsproblem, da adfærden synes at konstituere uærlighed eller som minimum grov forsømmelighed og dermed også plagiat. I udgangspunktet er det svært at forestille sig en redelig forklaring på forsker C’s adfærd. Nogle forskermiljøer vil evt. acceptere en tilbagetrækning eller korrektion af artiklen, men principielt set skal vedkommende have en påtale om videnskabeligt uredelig adfærd.

- Forsker D, der direkte har oversat en polsk tekst, gør sig skyldig i plagiat i dets ekstreme form, og situationen kræver en klar påtale om videnskabeligt uredelig adfærd.

\section{Fælles regler og fælles dømmekraft}

Med artiklens redegørelse for kriterier for videnskabelig uredelighed har det været hensigten, ikke bare at give et videnskabsteoretisk indblik og ideal, men at give et anvendeligt sæt kriterier, der kan benyttes i en konkret videnskabelig sag. Etableringen af retningslinjer er afgørende af den simple grund, at alle studerende og forskere så vidt muligt må følge de samme spilleregler for, at videnskaben kan fungere som praksis.

Enhver anvendelse kræver dog en fortolkning, og det er således ikke tilstrækkeligt blot at erklære sig enige om bestemte kriterier, men videnskaberne må også være opmærksom på at udøve en ensartet fortolkning af reglerne. Derfor må der etableres en form for udvalg, der kan komme til at fungere som en fælles dømmekraft. I Danmark står UVVU 
som et udvalg under Forskningsstyrelsen med ansvaret for at håndhæve den danske forsknings redelighed.

I forbindelse med oprettelsen af et udvalg, er der selvsagt mange overvejelser, der skal tages stilling til. I forlængelse af den danske situation og diskussion, er der udover den forvirrende udlægning af uredelighedsbegrebet to principielle punkter, der er værd at påpege: Hvorvidt et uredelighedsudvalg skal være landsdækkende, og hvorvidt udvalget skal have kompetence til ikke bare at påtale uredelig adfærd, men også brud på redelighedsnormer, der ikke involverer uærlighed eller grov forsømmelighed.

Sverige, Norge, Tyskland og Finland har forskellige former for landsdækkende udvalg, der står som garanter for, at der foreligger fælles nationale regler. I disse lande er det dog i udgangspunktet de enkelte forskningsinstitutioner, der håndterer en mistanke om videnskabeligt uredelig adfærd. I Danmark har Århus Universitet etableret et Praksisudvalg, der skal håndtere mistanker om videnskabelig uredelighed. F.eks. blev sagen om psykologen Helmut Nyborg behandlet af det lokale udvalg.

En fuldstændig omstrukturering af det danske system er formentlig ikke en reel mulighed, men enhver forskningsinstitution bør oprette et eget udvalg, så sager i første omgang kan behandles lokalt. Foregår denne behandling ikke på tilfredsstillende vis, kan et landsdækkende organ som UVVU stå som overdommer.

Spørgsmålet om, hvorvidt et udvalg skal have kompetence til at påtale mindre alvorlige overtrædelser af normer for god videnskabelig skik hænger tæt sammen med spørgsmålet om nationale vs. lokale udvalg. Mindre overtrædelser håndteres allerede i forvejen lokalt af arbejdsgiveren, der også har helt andre sanktionsmuligheder end et nationalt udvalg som UVVU. Et lokalt udvalg, evt. med rektor i spidsen, vil derfor kunne være tilknyttet dette ansvarsområde. Det vil samtidig være en fordel, at det nationale uredelighedsudvalg kun associeres med alvorlige tilfælde af uredelig adfærd, og ikke mindre overtrædelser. Det lokale udvalg bør endvidere samarbejde med det nationale udvalg om at eksplicitere og bevidstgøre kriterierne for videnskabelig uredelighed.

Nærværende artikel har forsøgt at give indblik i grundlæggende videnskabsteoretiske og videnskabsetiske refleksioner over, hvorledes ling- 
vistik bør forholde sig til videnskabelig uredelighed og det at arbejde etisk. Refleksionerne er afgørende for forskningens redelighed og dermed for dens status, berettigelse, forskningsmidler og politiske diskussioner. Diskussionen om videnskabelig uredelighed er således en uundværlig og uundgåelig diskussion.

\section{Litteraturliste}

Andersen, Daniel; Attrup, Lis; Axelsen, Nils; Riis, Povl 1992: Videnskabelig uredelighed og god videnskabelig praksis. Århus: Lægeforeningens forlag.

Bergenholtz, Carsten 2004: Den forvirrende uredelighed, Kronik i Berlingske Tidende, 16. januar 2004.

Hansen, Jens Morten 2003: Lomborg-sagen og debatten, www.forsk.dk/uvvu/nyt/presse/lomborg_pres.htm, (09.01.2003).

Rendtorff, Jacob Dahl 2003: Videnskabsetik. Frederiksberg: Roskilde Universitetsforlag.

UVVU 1996: Beretning 1995. København: Lægeforeningens Forlag, 1996.

UVVU 2003: Beretning 2002. København: Forskningsstyrelsen, 2003.

UVVU: UVVU's endelige afgørelse i klagesagen mod Bjørn Lomborg, www.forsk.dk/uvvu/nyt/presse/lomborg_presse.htm, (12.03.2004).

Vik, Anne Bjørnebye et al. 2001: Håndtering av uredelighet i forskningen. Oslo: Norges Forskningsråd.

Zahle, Henrik 2003: Uredelighed i forskningen. In Ugeskrift for Retsvæesen, Nr. 9, 91100. 